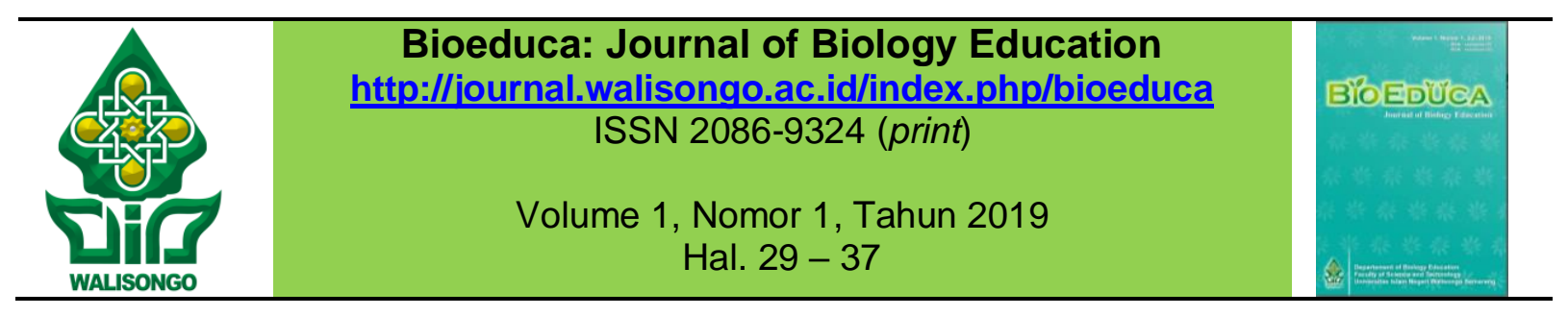

\title{
Pengaruh Keaktifan Siswa dalam Kegiatan Pramuka Terhadap Kepedulian Lingkungan Pesisir
}

\author{
Ikhwanuddin $^{1^{*}}$, Ikhrom ${ }^{2}$, Nur Hayati ${ }^{3}$ \\ ${ }^{1,3}$ Pendidikan Biologi, Universitas Islam Negeri Walisongo Semarang \\ ${ }^{2}$ Pendidikan Bahasa Inggris, Universitas Islam Negeri Walisongo Semarang \\ *Email: ikhwanfals33@gmail.com
}

\begin{tabular}{|c|c|}
\hline Informasi Artikel & ABSTRAK \\
\hline $\begin{array}{l}\text { Submit: } 10-08-2019 \\
\text { Diterima: } 12-08-2019 \\
\text { Dipublikasikan: } 31-09-2019\end{array}$ & $\begin{array}{l}\text { Penelitian ini dilakukan untuk mengetahui pengaruh keaktifan } \\
\text { siswa kelas X MA NU Nurul Huda dalam kegiatan Pramuka } \\
\text { terhadap kepedulian lingkungan pesisir. Penelitian ini } \\
\text { merupakan penelitian kuantitatif. Metode yang digunakan adalah } \\
\text { metode expost facto. Teknik pengambilan sampel secara } \\
\text { random, sebanyak } 108 \text { siswa. Data dari dokumentasi dan } \\
\text { angket, dianalisis dengan regresi sederhana. Instrumen diuji } \\
\text { validitas dan reliabilitasnya. Sedangkan pengujian hipotesis } \\
\text { melalui lima tahapan, yaitu uji keberartian korelasi, uji koefisien } \\
\text { korelasi pada regresi linier sederhana, koefisien determinasi, } \\
\text { persamaan regresi serta uji keberartian dan kelinieran regresi. } \\
\text { Hasil penelitian ini menunjukkan bahwa terdapat hubungan yang } \\
\text { signifikan antara keaktifan siswa kelas X MA NU Nurul Huda } \\
\text { Semarang dalam kegiatan Pramuka dengan kepedulian } \\
\text { lingkungan pesisir. Nilai kontribusi pengaruh keaktifan siswa MA } \\
\text { NU Nurul Huda Semarang terhadap kepedulian lingkungan } \\
\text { pesisir adalah sebesar } 12 \% \text {. } \\
\text { Kata kunci: keaktifan; kepedulian lingkungan; pramuka. }\end{array}$ \\
\hline Penerbit & ABSTRACT \\
\hline $\begin{array}{l}\text { Program Studi Pendidikan } \\
\text { Biologi, Fakultas Sains dan } \\
\text { Teknologi, UIN Walisongo } \\
\text { Semarang }\end{array}$ & $\begin{array}{l}\text { This research was conducted to know the influence of the } \\
\text { students activity of class X MA NU Nurul Huda in Scout activities } \\
\text { on coastal environmental awareness. This research is a } \\
\text { quantitative research, by expost-facto method. Data was } \\
\text { collected from } 108 \text { students as sample randomly. This study used } \\
\text { documentation and questionnaire for collecting data after validity } \\
\text { and reliability test for the instrument. Data was analyzed by } \\
\text { simple regression. The hypothesis was tested through five } \\
\text { stages, namely correlation significance test, correlation } \\
\text { coefficient test on simple linear regression, coefficient of } \\
\text { determination, regression equation and significance test and } \\
\text { linear regression. The result of this research shows that there is } \\
\text { a significant correlation between student activity of class X MA } \\
\text { NU Nurul Huda Semarang in scout activity with coastal } \\
\text { environmental concern. The contribution value of student } \\
\text { activeness influence of MA NU Nurul Huda Semarang toward } \\
\text { coastal environmental awareness is } 12 \% \text {. } \\
\text { Keywords: activity, environmental awareness, scout. }\end{array}$ \\
\hline
\end{tabular}

Copyright $(\mathcal{O} 2019$, Bioeduca: Journal of Biology Education 


\section{PENDAHULUAN}

Sikap peduli lingkungan dapat diwujudkan dengan kesadaran dari semua kalangan, baik tua maupun muda sebagai bagian dari masyarakat untuk menanamkan dalam diri masing-masing untuk mencegah kerusakan pada lingkungannya dan berupaya memperbaiki kerusakan yang sudah terjadi. Sikap peduli lingkungan harus ditanamkan sedini mungkin, mulai dari diri sendiri, keluarga, sekolah maupun masyarakat. Yusuf (2012) menyampaikan bahwa pengalaman masa kecil mempunyai pengaruh yang kuat terhadap perkembangan selanjutnya. Karakter peduli lingkungan bukanlah sepenuhnya talenta maupun insting bawaan, akan tetapi juga merupakan hasil dari suatu proses pendidikan dalam arti luas (Yusuf, 2012). Sikap kepedulian lingkungan harus mulai dilatih dari dalam diri sendiri maupun orang lain.

Pemerintah sebenarnya sudah menyadari tentang pentingnya kawasan pesisir dan lautan serta perlunya melindungi kualitas lingkungan pesisir dan laut. Hal ini dilihat dari penetapan Undang-undang Tahun 2014 Pasal 22 tentang Sumber Daya Pesisir dan Pulai-Pulau Kecil, Nomer 2A yang berisi Pemerintah dan Pemerintah Daerah sesuai dengan kewenangannya bertanggung jawab mengelola dan memanfaatkan sumberdaya pesisir dan pulau-pulau kecil dengan cara melindungi, mengonservasi, merehabilitasi, memanfaatkan, dan memperkaya sumberdaya pesisir dan pulau-pulau kecil serta sistem ekologisnya secara berkelanjutan (Saefudin, 2015).

Gerakan Pramuka adalah kegiatan ekstrakurikuler di sekolah yang melatih mental, kedisiplinan, membentuk rasa tanggung jawab, dan membina kepercayaan diri serta menumbuhkan sikap peduli terhadap lingkungannya. Laksono (2018) menemukan bahwa ektrakurikuler Pramuka berpengaruh terhadap kedisiplinan dan kemandirian siswa. Dengan mengikuti kegiatan Pramuka, siswa dilatih untuk siap menghadapi permasalahan apapun dan siap menghadapi tantangan. Gerakan Pramuka mempunyai peranan penting dalam mendidik dan membina kepribadian siswa, diantaranya adalah menumbuhkan rasa kepedulian terhadap lingkungannnya serta mampu mengatasi masalah-masalah yang terjadi di lingkungannya.

Gerakan pramuka sebagai wadah pembinaan generasi muda dengan menggunakan prinsip dasar metodik pendidikan kepramukaan, dipandang sebagai kelompok masyarakat yang perlu dimanfaatkan untuk mendukung kegiatan konservasi laut, pelestarian sumber daya alam, dan lingkungan hidup. Prinsip dasar kepramukaan adalah asas yang mendasari kegiatan kepramukaan dalam upaya membina watak anggota Pramuka, diantaranya adalah sebagai berikut:

a. Iman dan Taqwa kepada Tuhan Yang Maha Esa.

b. Peduli terhadap bangsa, negara, sesama manusia dan alam seisinya.

c. Taat kepada Kode Kehormatan Pramuka

Selain itu, keadaan lingkungan khususnya kawasan pesisir yang semakin hari semakin memprihatinkan, anggota Pramuka harus selalu siap dalam usaha menjaga kelestarian lingkungan. Melalui latihan Pramuka, siswa akan mendapatkan binaan, supaya memiliki pengetahuan yang luas dan juga diajak memahami masalah-masalah yang terjadi di masyarakat beserta belajar cara memecahkannya. 
Keaktifan adalah kegiatan yang bersifat fisik maupun mental, yaitu berbuat dan berfikir sebagai suatu rangkaian yang tidak dapat dipisahkan. Keaktifan siswa dalam mengikuti kegiatan Pramuka akan sangat mempengaruhi perilaku siswa dibandingkan dengan siswa yang tidak aktif dalam kegiatan Pramuka, sesuai dengan Kode Kehormatan Pramuka yaitu membentuk dan membina tingkah laku anggota Pramuka menuju hal-hal yang positif. Adapun indikator keaktifan siswa dalam kegiatan Pramuka, disesuaikan dengan pernyataan Mel Silberman (Suyadi, 2013), yaitu sebagai berikut:

a. Rasa ingin tahu (mendengar dan melihat supaya lebih paham)

b. Komunikatif (mendiskusikannya agar memahami atau mendalami)

c. Tanggung jawab (melakukannya agar memperoleh pengetahuan)

d. Kepedulian sosial (mengajarkannya agar menguasainya)

Masalah lingkungan penyebab utamanya adalah manusia sendiri. Manusia yang keliru, yang menyatakan bahwa manusia bukan bagian dari alam, tetapi sebagai makhluk yang berkuasa, penakluk dan pengatur alam. Selain itu manusia juga memiliki sifat dasar serakah dalam dirinya. Jika hal ini tidak diberikan solusi, maka akan terus berkembang tanpa kendali, sehingga keseimbangan lingkungan menjadi semakin buruk dan kerusakan alam akan terjadi dimana-mana. Sebagaimana firman Allah SWT dalam Al-Qur'an surat Ar-Rum ayat 41 (Depag RI, 2013) :

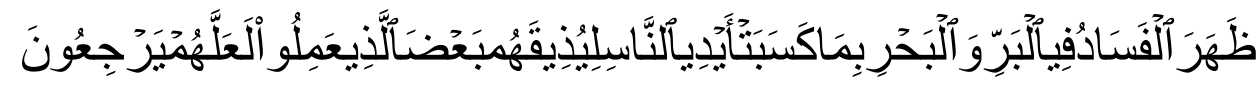

"Telah tampak kerusakan di darat dan di laut di sebabkan karena perbuatan tangan manusia, Allah menghendaki agar mereka merasakan sebagian dari (akibat) perbuatan mereka, agar mereka kembali (ke jalan yang benar)," (QS Ar-Rum : 41)

Sikap yang keliru, yang menyatakan bahwa manusia bukan bagian dari alam, tetapi sebagai makhluk yang berkuasa, penakhluk dan pengatur alam, justru menunjukan sifat kebinatangan dalam diri manusia. Sangat perlu untuk menanamkan sistem lingkungan yang menganggap manusia bagian dari alam kepada setiap individu masyarakat. Sebagaimana yang di ungkapkan Saifuddin, bahwa manusia memiliki tanggung jawab secara vertikal kepada Allah, dan petunjuk bagi manusia memelihara hubungan dengan dirinya sendiri, masyarakat dan alam semesta (Neolaka, 2008). Manusia seharusnya menyadari bahwa dirinya merupakan komponen biotik lingkungan hidup yang aktif, karena manusia dapat secara aktif mengelola dan mengubah ekosistem sesuai dengan apa yang dikehendaki. Sebagai makhluk yang paling sempurna, manusia wajib menjaga harmoni alam dan menyebarkan rahmat ke dalamnya, serta wajib melestarikan dan menjaga alam beserta isinya sebagai salah satu bentuk sikap peduli terhadap sesama makhluk. Peduli lingkungan menurut Kementerian Pendidikan Nasional adalah salah satu indikator nilai untuk pendidikan, budaya, dan karakter bangsa yang berdasar pada Agama, Pancasila, Budaya, dan Tujuan pendidikan Nasional. Hamzah mengungkapkan bahwa kepedulian lingkungan merupakan wujud sikap mental individu yang direfleksikan dalam perilakunya (Anwari, 
2014). Maka dapat disimpulkan bahwa kepedulian lingkungan adalah sikap atau karakter seseorang yang peka terhadap hal-hal yang berkaitan dengan lingkungan sekitar dan segera memperbaiki bila terjadi pencemaran atau ketidak seimbangan lingkungan.

Wilayah pesisir adalah suatu wilayah peralihan antara daratan dan laut. Mukhtashor, mengutip dari Bengen, mendefinisikan wilayah pesisir di daratan sebagai wilayah di mana daratan berbatasan dengan laut, yang masih dipengaruhi oleh proses-proses laut seperti pasang surut, angin laut, dan intrusi garam. Sedangkan batasan wilayah pesisir di laut adalah daerah yang dipengaruhi oleh proses-proses alami di daratan seperti sedimentasi dan mengalirnya air tawar ke laut, serta daerah laut yang dipengaruhi oleh kegiatan-kegiatan manusia di daratan (Mukhtashor, 2007).

Indikator siswa yang peduli lingkungan adalah sebagai berikut:

a. Menghindarkan dan menyelamatkan sumber bumi dari pencemaran dan kerusakan.

b. Menghindari tindakan-tindakan yang dapat menimbulkan pencemaran, merusak kesehatan dan lingkungan.

c. Memanfaatkan sumberdaya alam yang renewable (yang tidak dapat diganti) dengan sebaik-baiknya.

d. Memelihara dan memperbaiki lingkungan untuk generasi mendatang.

Generasi muda kini merupakan tunas-tunas muda harapan bangsa dalam pembangunan manusia seutuhnya dan masyarakat Indonesia seluruhnya. Melalui gerakan Pramuka, diharapkan remaja sebagai generasi penerus bangsa ini memiliki sikap kepedulian lingkungan yang tinggi. Sehingga tingkat laju kerusakan lingkungan khususnya di kawasan pesisir bisa semakin menurun. Karena alasan tersebut juga penelitian pengaruh keaktifan kegiatan Pramuka terhadap kepedulian lingkungan pesisir ini kami buat.

Penelitian ini bertujuan untuk mengetahui pengaruh keaktifan siswa dalam kegiatan Pramuka terhadap kepedulian ekosistem pesisir sehingga penelti merumuskan bahwa ada pengaruh keaktifan siswa dalam kegiatan Pramuka terhadap kepedulian ekosistem pesisir.

\section{METODE PENELITIAN}

Penelitian yang dilakukan oleh penulis adalah penelitian kuantitatif yaitu penelitian yang berlandaskan pada filsafat positivisme, digunakan untuk meneliti pada populasi atau sampel tertentu, teknik pengambilan sampel pada umumnya dilakukan secara random, pengumpulan data menggunakan instrument penelitian, analisis data bersifat kuantitatif/statistik dengan tujuan untuk menguji hipotesis yang telah ditetapkan (Sugiyono, 2010:124). Metode penelitian yang dilakukan yaitu dengan metode expostfacto, yaitu "dari apa yang dikerjakan setelah kenyataan", maka penelitian ini disebut sebagai penelitian sesudah kejadian. Penelitian expostfacto merupakan penelitian di mana variabel-variabel bebas telah terjadi ketika peneliti mulai dengan pengamatan variabel terikat dalam suatu penelitian (Sukardi, 2003:165). 
Peneliti melakukan penelitian terhadap sampel sejumlah 108 siswa dari jumlah keseluruhan 144 siswa, menggunakan 2 teknik pengumpulan data, yaitu Teknik Kuesioner (Angket) dan Dokumentasi. Kuesioner merupakan teknik pengumpulan data yang dilakukan dengan cara memberi seperangkat pernyataan tertulis kepada responden untuk menjawabnya. Dokumentasi adalah suatu teknik pengumpulan data dengan cara menghimpun dan menganalisis dokumen-dokumen, baik dokumen tertulis, gambar maupun elektronik.

Perolehan data dimulai dengan pemberian angket kepada 108 responden dengan angket yang sudah melalui tahap uji coba responden dan sudah di uji validitas dan releabilitas. Angket digunakan untuk mengetahui tingkat keaktifan siswa dalam kegiatan Pramuka dan tingkat kepedulian siswa terhadap lingkungan khususnya lingkungan pesisir di MANUNurul Huda Mangkangkulon Kota Semarang. Penelitian ini menggunakan angket tertutup dimana angket disusun menggunakan pilihan jawaban lengkap sehingga pengisi hanya tinggal memberi tanda pada jawaban yang dipilih (Arikunto, 2009). Baik keaktifan maupun kepedulian lingkungan, penilaian menggunakan acuan berupa skala bertingkat (Tabel 1).

Tabel 1. Kriteria Penilaian

\begin{tabular}{cc}
\hline Skala & Kategori \\
\hline 4 & Sangat baik \\
3 & Baik \\
2 & Cukup \\
1 & Kurang baik \\
\hline
\end{tabular}

Analisis selanjutnya yaitu uji hipotesis untuk mengetahui pengaruh keaktifan siswa dalam kegiatan Pramuka terhadap kepedulian lingkungan pesisir melalui tahapan uji keberartian koefisien korelasi, uji koefisien korelasi pada regresi linier sederhana, uji koefisisen determinasi, persamaan regresi sederhana dan uji keberartian dan kelinieran regresi.

\section{HASIL PENELITIAN DAN PEMBAHASAN}

Penelitian ini dilakukan pada tanggal 15 April 2017 s/d 29 April 2017 di Ambalan Ki Joko Tingkir - Nyi Ageng Manila Pangkalan MA NU Nurul Huda Kota Semarang yang bertempat di Kelurahan Mangkangkulon RT 4 RW 04, Kecamatan Tugu Kota Semarang, maka penulis memperoleh data hasil penelitian berupa angka-angka yang dianalisis untuk membuktikan hipotesis yang telah diajukan. Struktur organisasi dalam Dewan Ambalan Ki Joko Tingkir dan Nyi Ageng Manila setiap satu tahun sekali akan berganti, dilakukan dalam kegiatan Musyawarah Ambalan. Struktur kepenguran Ambalan terdiri dari KaMabigus yaitu Kepala Sekolah sendiri, KaGudep yang bisa dipilih dari WaKa Kesiswaan ataupun Guru yang lain. Pembina, Pradana, Pemangku Adat, Kerani, Juru Uang, Bidang TekPram, Bid. Rumah Tangga, Bid. Sosial Agama, dan Bidang Tata Usaha. Semua Bidang dari atas sampai ke Pembina semua terdiri dari putra dan putri ada orang yang mengisi, baik satu-satu maupun lebih dari satu, karena Gerakan Pramuka merupakan satuan terpisah. 
Keaktifan Siswa Kelas $X$ yang mengikuti kegiatan Pramuka melalui hasil angket, menunjukan bahwa terdapat 4 siswa yang berada dalam kategori sangat baik, 56 siswa berada dalam kategori baik, 43 siswa berada dalam kategori cukup dan 5 siswa yang berada kategori kurang terlihat pada Tabel 2 berikut:

Tabel 2. Kategori Keaktifan Siswa Kelas X Peserta Ekstrakurikuler Pramuka

\begin{tabular}{cccc}
\hline Interval & Jumlah Siswa & $\begin{array}{c}\text { Persentase Jumlah } \\
\text { Siswa }\end{array}$ & Kategori \\
\hline$\geq 3,25$ & 4 & $3,5 \%$ & Sangat baik \\
$>2,50-3,25$ & 56 & $52 \%$ & Baik \\
$>1,75-2,50$ & 43 & $40 \%$ & Cukup \\
$\leq 1,75$ & 5 & $4,5 \%$ & Kurang \\
\hline Total & 108 & $100 \%$ & \\
\hline
\end{tabular}

Keaktifan siswa MA NU Nurul Huda dalam mengikuti kegiatan Pramuka termasuk dalam kriteria baik. Aktif yang dimaksud di sini sebagaimana pernyataan Suyadi, "aktif" merupakan cerminan kerja keras, kemandirian, tanggung jawab, dan hasrat rasa ingin tahu (Suyadi, 2013:33).

Hasil angket mengenai kepedulian lingkungan pesisir memiliki skor tertinggi ideal 116. Skor-skor tersebut dikonversi ke skala 4 menggunakan acuan norma sebagaimana pada lampiran, menunjukan bahwa dari 108 responden, tidak ada siswa yang berada dalam kategori cukup maupun kurang. Terdapat 39 siswa dalam kategori baik dan 69 siswa berada dalam kategori sangat baik. Bisa disimpulkan bahwa siswa kelas X MA NU Nurul Huda memiliki kepedulian lingkungan pesisir yang sangat baik. Sebagaimana Tabel 3 berikut:

Tabel 3. Kategori Kepedulian Lingkungan Pesisir

\begin{tabular}{cccc}
\hline Interval & Jumlah Siswa & $\begin{array}{c}\text { Persentase Jumlah } \\
\text { Siswa }\end{array}$ & Kategori \\
\hline$\geq 3,25$ & 69 & $64 \%$ & Sangat baik \\
$>2,50-3,25$ & 39 & $36 \%$ & Baik \\
$>1,75-2,50$ & 0 & $0 \%$ & Cukup \\
$\leq 1,75$ & 0 & $0 \%$ & Kurang \\
\hline Total & 108 & $100 \%$ & \\
\hline
\end{tabular}

Angket yang disebar untuk perolehan data sebelumnya dilakukan terlebih dahulu uji coba instrument, untuk mengetahui apakah butir angket sudah memenuhi kualitas instrumen yang baik atau belum. Uji coba tersebut dilakukan sebelum angket diberikan kepada responden. Adapun alat yang digunakan dalam pengujian instrumen meliputi uji validitas dan uji reliabilitas.

Uji validitas dilakukan dengan cara menyebar instrumen kepada 40 siswa kelas XI dan XII yang sudah pernah mengikuti kegiatan Pramuka. Uji validitas ini digunakan untuk mengetahui valid atau tidaknya butir-butir instrumen. Untuk mengetahui validitas butir-butir instrumen untuk variabel keaktifan siswa dalam kegiatan Pramuka $(X)$ dan 
Variabel kepedulian terhadap lingkungan pesisir $(\mathrm{Y})$ digunakan rumus korelasi product moment, rumusnya adalah sebagai berikut :

$$
r_{x y}=\frac{N \Sigma X Y-(\Sigma X)(\Sigma Y)}{\sqrt{\left[N \Sigma X^{2}-(\Sigma X)^{2}\right]\left[N \Sigma Y^{2}-(\Sigma Y)^{2}\right]}}
$$

Butir pernyataan yang valid tetap digunakan untuk memperoleh data sedangkan pernyataan yang tidak valid tidak digunakan atau dibuang jika masih ada pernyataan lain yang mewakili indikator yang dibutuhkan. Hasil analisis perhitungan validitas butir-butir instrumen $r_{x y}$ dikonsultasikan dengan harga kritik $\mathrm{r}$ product moment dengan taraf kesalahan $5 \%$. Bila harga $r_{x y}>r_{\text {tabe/ }}$ maka butir-butir soal tersebut dikatakan valid, sedangkan jika $r_{x y}<r_{\text {tabel }}$ maka butir-butir soal dikatakan tidal valid. Instrumen yang tidak valid selanjutnya dibuang karena masih ada butir pernyataan lain yang mewakili indikator, sedangkan pada instrumen yang valid akan dilakukan uji reliabilitas.

Uji reliabilitas digunakan untuk mengetahui tingkat konsistensi jawaban instrumen. Instrumen yang baik secara akurat akan memiliki jawaban yang konsisten. Data uji reliabilitas dapat dilihat di lampiran kemudian dihitung dengan menggunakan rumus :

$$
r_{11}=\left(\frac{\mathrm{n}}{\mathrm{n}-1}\right)\left(\frac{\mathrm{S}^{2}-\sum \mathrm{pq}}{\mathrm{S}^{2}}\right)
$$

Harga $r_{11}$ yang diperoleh kemudian dikonsultasikan dengan harga $r_{\text {tabel }}$ product moment dengan taraf signifikan $5 \%$. Soal dikatakan reliabel jika harga $r_{11}>r_{\text {tabel }}$. Hasil perhitungan uji instrumen pada lampiran, diperoleh nilai reliabilitas instrumen keaktifan siswa dalam mengikuti kegiatan Pramukar ${ }_{11}=1,035$ dengan taraf signifikan 5\% diperoleh $r_{\text {tabel }}=0,312$. Sedangkan nilai reliabilitas instrument kepedulian lingkungan pesisir $r_{11}=1,032$ dengan taraf signifikan $5 \%$ diperoleh $r_{\text {tabel }} 0,312$. Setelah dibandingkan antara $r_{\text {tabel }}$ dan $r_{\text {hitung. }}$. Ternyata $r_{\text {hitung }}>r_{\text {tabel }}$ berarti butir-butir instrumen termasuk reliabel maka pernyataan-pernyataan pada instrumen dapat digunakan.

Analisis selanjutnya yang dilakukan guna menguji hipotesis adalah uji korelasi. Hasil perhitungan pada uji korelasi secara manual dan dipadukan dengan bantuan program SPSS versi 16.0, menunjukan harga t adalah 3,796 untuk $X$ dan $Y$. Harga ini dikonsultasikan dengan $d k=108$ dan taraf signifikansi $5 \%$ diperoleh tabel $=1,658$. $t_{\text {hitung }}>$ trabel maka $\mathrm{H}_{a}$ diterima sehingga terdapat pengaruh yang positif dan signifikan antara keaktifan siswa dalam kegiatan Pramuka $(X)$ terhadap kepedulian lingkungan pesisir ( $Y$ ). Hasil tersebut menunjukan bahwa semakin tinggi keaktifan siswa dalam kegiatan Pramuka maka semakin tinggi pula kepeduliannya terhadap lingkungan pesisir. Sebaliknya semakin rendah keaktifan siswa dalam kegiatan Pramuka maka semakin rendah pula kepeduliannya terhadap lingkungan pesisir.

Hubungan antara variabel $X$ dan $Y$ pada penelitian ini tergolong rendah. Nilai $r$ $=0,346$ termasuk dalam kategori rendah. Indeks korelasi determinan dari pengaruh keaktifan siswa kelas X MA NU Nurul Huda Semarang dalam mengikuti kegiatan Pramuka terhadap kepedulian lingkungan pesisir menggunakan rumus $\mathrm{Kp}=r^{2} \times 100 \%$ 
adalah $12 \%$. Sedangkan pengaruh lain yang mempengaruhi kepedulian siswa terhadap lingkungan pesisir sebesar $88 \%$ tidak dijelaskan dalam penelitian ini.

Analisis regresi sederhana dari rumus $\hat{Y}=a+b X$ menunjukan persamaan garis linier sederhana $\hat{Y}=79,721+0,276 X$. Jika $X=0$ (keaktifan siswa dalam kegiatan Pramuka tidak ada), maka diperoleh persamaan $\hat{Y}=79,721$. Artinya masih tetap diperoleh skor sikap kepedulian lingkungan pesisir sebesar 79,721. Hal ini menunjukkan bahwa nilai $\hat{Y}$ tidak hanya dipengaruhi oleh $X$ saja, tetapi ada faktor lain yang juga mempengaruhinya.

Nilai $\mathrm{F}$ pada tabel Anava menunjukan $F=\frac{S_{r e g}^{2}}{S_{\text {sis }}^{2}}\left(F_{\text {hitung }}\right)=14,38857$. Nilai tersebut dikonsultasikan dengan $F_{\text {tabel }}$ dengan taraf signifikansi $5 \%, d k$ pembilang $=1$ dan $d k$ penyebut $=n-2=108-2=106$ adalah 3,94. Karena $F_{\text {hitung }}>F_{\text {tabel }}$ maka koefisien arah regresi itu berarti. Kelinearitas dapat dilihat dari $F=\frac{S_{T C}^{2}}{S_{G}^{2}}\left(F_{\text {hitung }}\right)=-1,718$. Nilai tersebut dikonsultasikan dengan $F_{\text {tabel }}$ dengan taraf signifikansi $5 \%$, dk pembilang ( $k-$ 2) $=41-2=39$ dan $d k$ penyebut $(n-k)=108-41=67$ adalah 1,63. Karena $F_{\text {hitung }}<F_{\text {tabel }}$ maka regresi linear.

Data angket kepedulian lingkungan pesisir yang telah dibagikan kepada 108 responden anggota Gerakan Pramuka MA NU Nurul Huda Mangkangkulon Kota Semarang menunjukan hasil kriteria siswa kelas X MA NU Nurul Huda sebagai anggota wajib kegiatan Pramuka memiliki tingkat kepedulian lingkungan pesisir yang baik, sebagaimana penulis cantumkan hasil perhitungannya pada lampiran tabel skor kepedulian lingkungan pesisir yang sudah dikonversi dengan skala 4 acuan norma. Hal ini berarti siswa-siswi anggota kegiatan Pramuka MA NU Nurul Huda Semarang termasuk dalam kategori baik dalam kegiatan yang bersifat pencegahan kerusakan lingkungan serta mengupayakan untuk memperbaiki lingkungan yang telah rusak, seperti kegiatan penghijauan, kerja bakti membersihkan lingkungan, menjaga kebersihan, menggunakan barang-barang yang tidak dapat diperbarui dengan sebaikbaiknya, mengupayakan kelestarian lingkungan serta melakukan berbagai kegiatan lainnya, sebagai usaha dalam menjaga keseimbangan lingkungan. Sebagaimana penelitian yang dilakukan oleh Heryanti et al. (2016) bahwa terdapat korelasi antara partisipasi siswa dalam ekstrakurikuler Pramuka dengan sikap kepedulian lingkungan hidup.

\section{SIMPULAN DAN SARAN}

Berdasarkan hasil penelitian dan analisis data tersebut dapat disimpulkan bahwa terdapat pengaruh yang positif dan signifikan antara keaktifan siswa dalam kegiatan Pramuka terhadap kepedulian lingkungan pesisir. Hal tersebut dapat dilihat dari hasil uji korelasi yang menunjukkan nilai thitung $3,796>t_{\text {tabel }} 0,361$ dengan taraf signifikansi 0,05 , sedangkan $R^{2}=0,12$ menunjukkan tingkat pengaruh yang rendah dengan interval koefisien 0,20-0,399. Hasil analisis regresi ditunjukkan dengan $F_{\text {reg }}=$ 14,388> $F_{\text {tabel }} 0,05 \quad(3,94)$ bahwa keaktifan siswa dalam kegiatan Pramuka berpengaruh positif terhadap kepedulian lingkungan pesisir. Hasil tersebut dapat disimpulkan bahwa semakin tinggi keaktifan siswa dalam kegiatan Pramuka, semakin 
tinggi sikap kepeduliannya terhadap lingkungan pesisir. Sebaliknya, semakin rendah keaktifan siswa dalam kegiatan Pramuka, semakin rendah pula sikap kepeduliannya terhadap lingkungan pesisir. Saran untuk penelitian mendatang dapat diperluas sasaran sampelnya sehingga diperoleh data yang lebih terpercaya.

\section{RUJUKAN}

Anwari.A, \& Mukminin A. (2014). Strategi pembentukan karakter peduli lingkungan di sekolah adiwiyata. TA'DIB, 19(2): 229

Arikunto, S. (2009). Dasar-dasar Evaluasi Pendidikan. Jakarta: Bumi Aksara.

Syaifuddin, A. (1999). Penyusunan Skala Psikologi. Yogyakarta: Pustaka Pelajar.

Departemen Agama Rl. (2002). Alqur'an dan Terjemahnya. Jakarta Timur: CV. Darus Sunnah.

Heryanti, E., Matondang, M. N., \& Wati, D. A. (2018). Hubungan Antara Partisipasi Siswa dalam Kegiatan Ekstrakurikuler Pramuka dengan Sikap Kepedulian Lingkungan Hidup. Biosfer: Jurnal Pendidikan Biologi, 9(2), 54-59.

Kumurur, Veronica A. (2008). Pengetahuan, Sikap dan Kepedulian Mahasiswa Pascasarjana IImu Lingkungan Terhadap Lingkungan Hidup Kota Jakarta. EKOTON. 8(2):1-24.

Kwartir Nasional Gerakan Pramuka. (1979). Keputusan Kwartir Nasional Gerakan Pramuka Nomor 036 . Jakarta.

Laksono, F., \& Widagdo, A. (2018). Pengaruh Ekstrakurikuler Pramuka Terhadap Kedisiplinan Dan Kemandirian Siswa. Joyful Learning Journal, 7 (1), 63-71.

Mukhtashor. (2014). Pencemaran Pesisir dan Laut. Jakarta: CV Alika.

Mustari, Mohammad. (2017). Nilai Karakter Refleksi Untuk Pendidikan. Jakarta; PT Grafindo Persada.

Nurul Fajri Chikmawati. (2013). Pengelolaan Wilayah Pesisir dan pulau Pulau Kecil di Indonesia. ADIL. Jurnal Hukum. Vol 4 No 2.

Siti Rifatul Munawaroh, Ismail, Bunga Ihda Norra. (2018). Pengembangan instrumen penilaian kompetensi inti keterampilan (KI-4) pada pembelajaran biologi kurikulum 2013 materi sistem peredaran darah manusia kelas VIII di SMP Negeri 3. Skripsi Pendidikan Biologi Fakultas Sains dan Teknologi UIN Walisongo Semarang.

Sugiyono. (2012). Metode Penelitian Pendiidkan Pendekatan Kuantitatif, Kualitatif, dan $R \& D$. Bandung: Alfabet.

Sukardi. (2003). Metodologi Penelitian Pendidikan. Jakarta: PT. Bumi Aksara.

Suyadi. (2013). Strategi Pembelajaran Pendidikan Karakter, Bandung: PT Remaja Rosdakarya Offset. 